\title{
CUTANEOUS EFFECTS OF SEA BUCKTHORN OIL EMULSION
}

Mihailo Kipic ${ }^{1}$, Snezana Cupara ${ }^{1}$, Vesna Jacevic ${ }^{2}$, Ana Radovanovic ${ }^{1}$, Olivera Milovanovic ${ }^{1}$

${ }^{1}$ Faculty of Medical Sciences, University of Kragujevac, 34000 Kragujevac, Serbia

${ }^{2}$ National Poison Control Centre, Military Medical Academy, 11000 Belgrade, Serbia

\author{
PERKUTANI EFEKAT EMULZIJE SA ULJEM PASJEG TRNA \\ Mihailo Kipić1, Snežana Cupara ${ }^{1}$, Vesna Jaćević ${ }^{2}$, Ana Radovanović ${ }^{1}$, Olivera Milovanović ${ }^{1}$ \\ ${ }^{1}$ Fakultet medicinskih nauka, Univerzitet u Kragujevcu, 34000 Kragujevac, Srbija \\ ${ }^{2}$ Centar za kontrolu trovanja, Vojnomedicinska akademija, 11000 Beograd, Srbija
}

\section{ABSTRACT}

Sea buckthorn oil (Hippophae rhamnoides L.) is medically used both externally and internally, but the external application is unsuitable due to its liquid, lipophilic and highly coloured nature. These difficulties could be overcome by a formulation of semisolid emulsion with sea buckthorn oil. Previous research on this formulation showed that it has higher wound healing potential than sea buckthorn oil, possessing an enhanced structure of liquid crystals, stability and suitability for topical use.

The aim of this investigation was to completely characterizise a proposed emulsion by testing skin effects, such as moisturising potential, skin $\mathrm{pH}$ and potential to cause skin irritation.

The emulsion was prepared by standard emulsifying techniques using a combination of surfactants that form an enhanced structure of liquid crystals. Approximately $40 \%$ of sea buckthorn oil was incorporated. The moisturising potential and skin $\mathrm{pH}$ were tested on the healthy skin of volunteers. Skin tolerance was tested on a rabbit skin model and evaluated by the Draize test.

The tested emulsion containing sea buckthorn oil did not cause a significant change in skin $\mathrm{pH}$, while it significantly increased skin hydration. There was an absence of edema or erythema type of irritation after $2 h, 24 h, 48 h, 72 h$ and 7 days of application of the emulsion with sea buckthorn oil.

The tested formulation shows good moisturizising effects and does not cause human or animal skin irritation. The study confirms that the combination of the proposed ingredients in a sea buckthorn oil emulsion is adequate and could be safe for skin application.

Key words: sea buckthorn oil, emulsion, topical use, irritation

\section{SAŽETAK}

Ulje pasjeg trna (Hippophae rhamnoides L.) se u medicinske svrhe upotrebljava kako za eksternu tako $i$ za internu primenu, pri čemu je eksterna primena nepogodna usled njegove tečne konzistencije, lipofilne prirode $i$ intenzivne obojenosti. Navedeni nedostaci bi se mogli prevazići formulacijom polučvrstih emulzija sa uljem pasjeg trna. Prethodna ispitivanja ove formulacije su pokazala da poseduje znatno veći potencijal za zarastanje rana u odnosu na ulje pasjeg trna, unapređenu strukturu tečnih kristala, stabilnost i pogodnost za lokalnu primenu.

Sprovedeno istraživanje imalo je za cilj da upotpuni karakterizaciju predložene formulacije, testirajući efekte na koži-hidrirajući potencijal, pH kože i potencijal za izazivanje kožnih iritacija.

Emulzija je pripremljena standardnim tehnikama emulgovanja, korišćenjem kombinacije surfaktanata kojima se formira poboljšana struktura tečnih kristala pri čemu je ulje pasjeg trna je bilo inkorporirano u količini od $40 \%$. Hidrirajući potencijal i pH kože su bili testirani na koži $z$ dravih volontera. Tolerancija kože je testirana na modelu zečje kože i procenjivana pomoću Draize-ovog testa.

Ispitivana emulzija sa uljem pasjeg trna nije pokazala značajne promene pH kože, dok je pokazan značajan hidrirajući efekat. Nisu se javile kožne iritacije, tipa edema ili eritema, nakon $2 h, 24 h, 48 h, 72 h i 7$ dana od aplikacije emulzije sa uljem pasjeg trna.

Evaluirana formulacija ne izaziva iritaciju ni humane ni životinjske kože i pokazuje dobar hidrirajući efekat. Studija potvrduje da je kombinacija preloženih sastojaka u emulziji sa uljem pasjeg trna adekvatna $i$ može se bezbedno primenjivati na koži.

Ključne reči: ulje pasjeg trna, emulzija, lokalna primena, iritacija 


\section{INTRODUCTION}

Hippophae rhamnoides L. (sea buckthorn) is a bushy tree growing both in Asia and Europe (1). European northern habitats are located in Germany, while the southern habitats are located near the Black Sea. Hippophae rhamnoides L. grows in the Caucasus, Alps and Carpathians and in the Danube delta, and it exists as a cultivated species in Germany and Russia (2). In the past, it was also identified in Serbia near the Danube $(3,4)$.

Although different parts of sea buckthorn have been studied (e.g., fruits, leaves), the research on its fruits is the most abundant. The fruits are round and fleshy and are predominantly of an orange colour (4). The pulp has a mild smell and is oily due to considerable fatty oil content. The fruits are collected from September to late December and are considered a high source of vitamin $\mathrm{C}$ and fatty oil, the chemical composition of which depends on harvesting time (5-10).

Medical research on sea buckthorn increased at the end of XX century. Analysis of the chemical content of the fruit pulp and oil revealed a rather unusual combination of sea buckthorn oil constituents - saturated and unsaturated fatty acids (palmitic, palmitoleic, oleic, linoleic, linolenic, myristic, stearic), vitamin $\mathrm{A}$, vitamin $\mathrm{E}$, beta carotene, sterols, etc. (10-12). Positive pharmacologic effects of sea buckthorn oil on human health are linked to both external and internal application (7). When externally applied, tissue-regenerative, anti-inflammatory, anti-oxidant and anti-bacterial effects were observed in wounds, burns, and atopic dermatitis. Topical use of sea buckthorn oil applied to burns stimulates the proliferation of fibroblasts, collagen synthesis, the expression of specific matrix metalloproteinases, and angiogenesis, which has been connected to a high content of unsaturated omega- 3 and omega- 6 fatty acids, carotenoids and tocopherols in oil $(6,7,13,14)$.

The sea buckthorn oil used in this investigation was obtained from fruits from spontaneous flora (12). It was an orange, lipophilic liquidand and was difficult to apply externally in a reproducible manner. A semisolid topical formulation of an emulsion was proposed to overcome

Table 1. Formulation of semisolid emulsion with sea buckthorn oil

\begin{tabular}{|l|l|l|}
\hline \multirow{5}{*}{ Inner/oily phase: } & Components & $\%(\mathrm{~m} / \mathrm{m})$ \\
\cline { 2 - 3 } & Lanette $^{\circ} 16$ & 2.0 \\
\cline { 2 - 3 } & Lanette $^{\circ} 18$ & 2.0 \\
\cline { 2 - 3 } & Brij $^{\circ} 72$ & 2.5 \\
\cline { 2 - 3 } & Brij $^{\circ} 721 \mathrm{P}$ & 2.5 \\
\cline { 2 - 3 } & Arlamol E & 4.00 \\
\cline { 2 - 3 } & Hippophae oleum & 40.00 \\
\hline \multirow{3}{*}{$\begin{array}{l}\text { Outer/water } \\
\text { phase: }\end{array}$} & Nipagin & 0.10 \\
\cline { 2 - 3 } & Propylene glycol & 3.00 \\
\cline { 2 - 3 } & Aqua purificata & 43.90 \\
\hline
\end{tabular}

obstacles in application (dripping, leaking, and difficult absorption). Previous pharmaceutical and pharmacological research on this formulation showed that it enhances wound healing and possesses the following characteristics - an oil/water type, an acceptable $\mathrm{pH}$ value and organoleptic properties for skin application $(15,16)$. The aim of this study was to complete previous studies of the proposed formulation by evaluating the following effects on human and animal skin: moisturising potential, change of skin $\mathrm{pH}$ after application, and potential to cause skin irritation.

\section{MATERIALS AND METHODS}

For the preparation of the test emulsion, we used sea buckthorn oil obtained from plant material ex tempore (4). The substances, separated as an inner or outer phase based on lipophilic and hydrophilic affinity, were merged together (Table 1.). The emulsion was prepared by standard emulsifying techniques, and a sample with $40 \%$ sea buckthorn oil was prepared $(15,16)$. Standard laboratory equipment was used, including a digital balance (Chyo, MP-3000, Japan), water bath (Sutjeska, Belgrade, Republic of Serbia) and laboratory mixer (Velp, EU). Samples of the emulsion with sea buckthorn oil (SB) were packed in tubes and sealed immediately after the preparation.

Skin moisture and skin $\mathrm{pH}$ were tested on 12 healthy women, with an average age of 45.5 years. The samples were applied twice daily for 28 days, after which there was a pause of one week with no application. The last measurement was done on the $35^{\text {th }}$ day. The volunteers were aware that 3 days before the application of the examined preparation, they should not apply any dermatological or cosmetic products on the place of the application (the inner under-elbow surface of the skin). The volunteers were placed in a room with constant conditions (temperature $22 \pm 1^{\circ} \mathrm{C}$, humidity $\left.55 \pm 5 \%\right) 20 \mathrm{~min}$ prior to the testing. The measurements of the skin moisture were done on days 1, 3, 5, 7, 14, 21, 28 and 35 by a CorneometerCM 820 (Courage+Khazaka Elektronic, Germany). Skin pH was measured by a Skin-pH-meter PH900 (Courage+Khazaka Elektronic, Germany) on days 1-9. A $2 \mathrm{mg} / \mathrm{cm}^{2}$ dose of the sample was applied on the insides of forearms $\left(9 \mathrm{~cm}^{2}\right)$. The Student's t-test $(\mathrm{p}<0.05)$ and ANOVA were used to evaluate the statistical significance of the measured differences.

To evaluate the potential of the proposed formulation to cause irritation, an animal model was used. The experiment was conducted on male rabbits, with a body weight of $2.0-2.5 \mathrm{~kg}$. Rabbits were accommodated, one per cage, under conditions of controlled temperature and lighting, with food and water provided ad libitum. To adapt to the environment, the animals were kept in the cages at room temperature. A circadian regime, light/dark ratio of $12 / 12$, was used during seven days before the experiment. The temperature was $22-26^{\circ} \mathrm{C}$, and the relative humidity was $30-70 \%$. The food and water provided were standard laboratory food for rabbits (Veterinarski Zavod Subotica, 
Table 2. Intensity level of skin changes of rabbit skin (Draize test)

\begin{tabular}{|l|l|l|}
\hline Parameters & Level \\
\hline Edema (Ed) & Erythema (Er) & \\
\hline No edema & No erythema & 0 \\
\hline Slightly visible edema & Mild, slightly visible erythema & 1 \\
\hline Edema with visible border & Well expanded erythema & $2^{*}$ \\
\hline Moderate edema $-\leq 1 \mathrm{~mm}$ & Moderate to strong erythema & $3^{*}$ \\
\hline Heavy edema $-\geq 1 \mathrm{~mm}$ & Heavy erythema and crust & $4^{*}$ \\
\hline
\end{tabular}

"positive findings

Serbia) and did not contain substances that could have influenced their health. The study protocol was based on the Guidelines for Animal Study No. 282-12/2002 of the Military Medical Academy Ethics Committee, Belgrade, Serbia.

The animals were randomly divided into 3 groups of 3 animals and were treated in the following way: the 1st group was the control group and received saline solution $0.9 \% \mathrm{NaCl}$, the 2 nd group received only sea buckthorn oil, and the 3rd group received samples of the emulsion containing sea buckthorn oil. Rabbit use is approved for testing skin tolerance and irritation potential during external application $(17,18)$.

Before application of the test substance, a dorsolateral skin surface of $\sim 20 \mathrm{~cm}^{2}$ was depilated on both sides. The test substance was applied once daily in the quantity of 5 $\mathrm{ml}$ on the prepared area of the skin. After sample application, the depilated area was covered by a sterile cotton cloth and fixed by a non-irritative bandage for $4 \mathrm{~h}$. Skin changes were observed after 2, 24, 48 and $72 \mathrm{~h}$ and 7 days after application of the test substance, and intensity was graded according to the Draize test (Table 2.) $(19,20)$.

\section{RESULTS}

The test sample of the emulsion containing sea buckthorn oil was semisolid and homogeneous, and it did not cause any allergic reactions or other side effects during the testing.

There was significant change in skin moisture that started on day 3 compared to the baseline value, registered on the first day after sample application, and continued until day 28 inclusive. The highest value for skin moisture was on day 3 (increase of $10.31 \%$ ). A pause of one week influenced the change in skin moisture, and a 1.64\% decrease from the baseline value was noted. The results are shown in Fig. 1.

External application of the tested emulsion did not significantly change the $\mathrm{pH}$ of the healthy skin. The results are shown in Fig. 2.

The results of the emulsion sample application on rabbit skin are shown in Table 3. There was no evidence of edema or erythema in any of the 3 animal groups during the experiment.

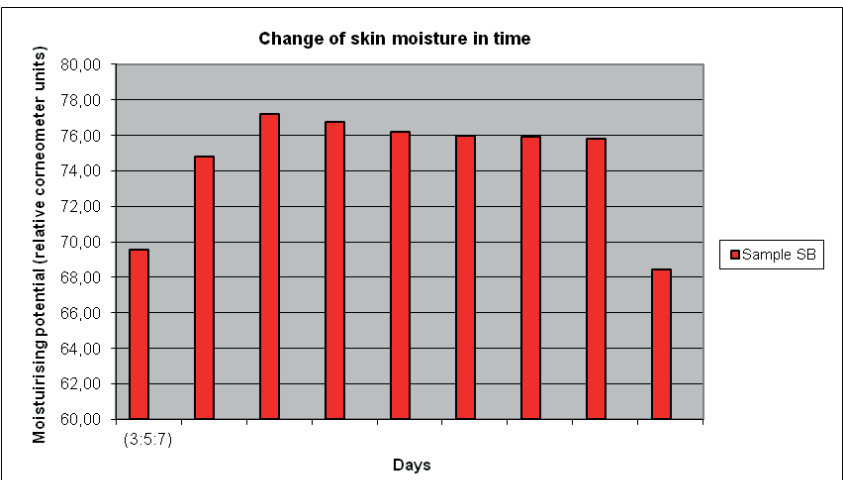

Figure 1. Skin moisturising effect of the emulsion with sea buckthorn oil

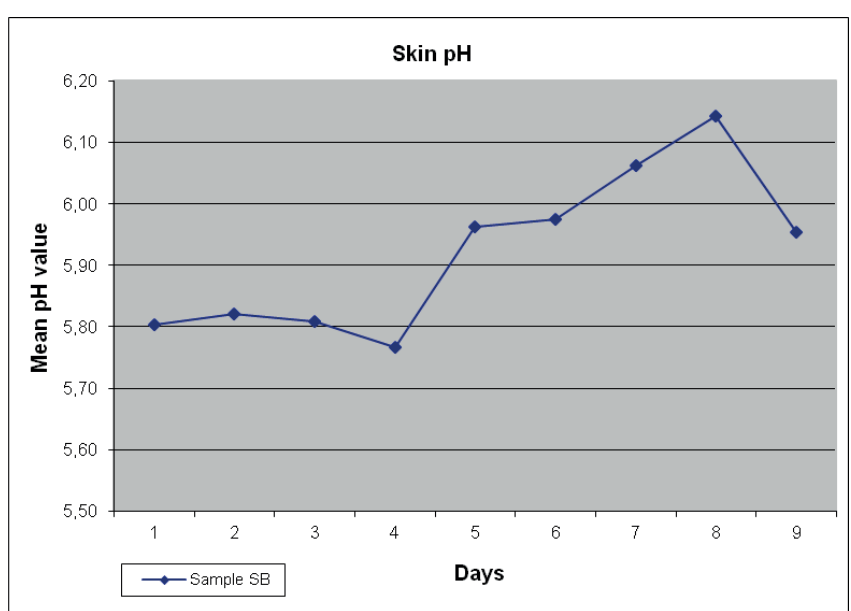

Figure 2. The mean skin $\mathrm{pH}$ value of healthy volunteers

\begin{tabular}{|c|c|c|c|c|c|c|c|c|c|c|}
\hline \multirow{3}{*}{ Treatment } & \multicolumn{10}{|c|}{ Level of skin change } \\
\hline & \multicolumn{2}{|l|}{$2 \mathrm{~h}$} & \multicolumn{2}{|c|}{$24 \mathrm{~h}$} & \multicolumn{2}{|c|}{$48 \mathrm{~h}$} & \multicolumn{2}{|c|}{$72 \mathrm{~h}$} & \multicolumn{2}{|c|}{7 days } \\
\hline & $E d$ & $E r$ & $E d$ & $\mathrm{Er}$ & $E d$ & Er & $E d$ & $\mathrm{Er}$ & $E d$ & $\mathrm{Er}$ \\
\hline Sol. $0.9 \% \mathrm{NaCl}$ & 0 & 0 & 0 & 0 & 0 & 0 & 0 & 0 & 0 & 0 \\
\hline Sea buck. oil & 0 & 0 & 0 & 0 & 0 & 0 & 0 & 0 & 0 & 0 \\
\hline Emulsion & 0 & 0 & 0 & 0 & 0 & 0 & 0 & 0 & 0 & 0 \\
\hline
\end{tabular}

Table 3. Results of testing the irritation-causing potential of the emulsion with sea buckthorn oil on rabbit skin 


\section{DISCUSSION}

Sea buckthorn oil has anti-inflammatory and epithelisation stimulating properties $(7,15)$. As a lipophilic liquid, sea buckthorn oil can have the main or adjuvant role in the formulation of a semisolid topical emulsion. Previous research on this formulation showed that it's application resulted in better wound healing than sea buckthorn oil, which may be attributed to the structure of the emulsion (liquid crystals) and the synergetic activity of sea buckthorn oil and other ingredients (17). Testing additional skin effects of the proposed emulsion (skin moisturising effects, $\mathrm{pH}$ change on healthy human skin, and potential to cause irritation on rabbit skin) completed the evaluation of the proposed emulsion for external use, because the enhanced structure of the liquid crystals should provide proper skin hydration $(21,22)$. Surfactants in emulsion are used for formulation stability but, at the same time, may often cause skin irritation as an undesirable side effect. The modern approach in emulsion formulation is to choose a combination of surfactants not only to achieve a better stabilisation effect, but also to minimise the potential for skin irritation. Surfactants may disturb metabolism of lipids, which are an integrative part of the stratum corneum. Direct contact of surfactants with epidermal layer of keratinocytes may cause inflammation or cytotoxicity due to the release of proinflammatory cytokines or protein denaturation, leadin $g$ to swelling of the stratum corneum and breaking the natural barrier function of the skin $(23,24)$. The effects surfactants may present on the skin depend on their type and concentration, as well as on their interactions with other ingredients used in the formulation. A successful formulation should provide both emulsion stability and good skin tolerance $(25,26)$. The proposed formulation is well stabilised by liquid crystals and has good skin characteristics $(17,27)$. Testing cutaneous effects represents an integral part of the evaluation for topical formulations and completes findings about this formulation. Because the application of the proposed emulsion with sea buckthorn oil did not cause any irritation, it seems that all ingredients used in this formulation are adequate for skin application. Thus, we can conclude that this formulation is suitable for external application.

\section{CONCLUSION}

This work completely characterizises information about the proposed formulation studied earlier. There was good skin tolerance of the proposed emulsion on both human and animal skin. It did not significantly change the skin $\mathrm{pH}$ and has good moisturising potential for human skin. It did not cause irritation on human or rabbit skin after topical application. This research shows that the quantities and type of components used in the proposed emulsion with sea buckthorn oil are adequate for safe external application.

\section{REFERENCES:}

1. Rousi A. The genus Hippophae L. - A taxonomic study. Annales Botanici Fennici 1971; 8: 177-227.

2. Brad I. Catina alba. Bucuresti: Editura tehnica, 2002.

3. Tucakov J. Lečenje biljem - fitoterapija. Beograd: Rad, 1990.

4. Sarić M. Lekovite biljke SR Srbije. Beograd: Srpska akademija nauka i umetnosti, 1989.

5. Ganju L, Padwad Y, Singh R, et al. Anti-inflammatory activity of sea buckthorn (Hippophae rhamnoides L.) leaves. Int Immunopharmacol 2005; 5: 1675-84.

6. Upadhyay NK, Kumar R, Mandotra SK, et al. Safety and healing efficacy of Sea buckthorn (Hippophae rhamnoides L.) seed oil on burn wounds in rats. Food Chem Toxicol 2009; 47: 1146-53.

7. Yang B, Kallio H. Composition and physiological effects of sea buckthorn (Hippophae) lipids. Trends Food Sci Technol 2002; 13: 160-7.

8. Yang B, Kallio H. Effects of Harvesting Time on Triacylglycerols and Gycerophospholipids of Sea Buckthorn (Hippophae rhamnoides L.) Berries of Different Origins. J Food Compost Anal 2002; 15: 143-57.

9. Li TS, Schroeder WR. Sea Buckthorn (Hippophae rhamnoides L.): A multipurpose plant. HortTech 1996; 6: 370-80.

10. Mironov VA, Guseva-Donskaya TN, Dubrovina YY, et al. Chemical composition and biological activity of extracts from sea buckthorn fruit components. KhimikoFarmatsevticheskii Zhurnal 1989; 23: 1357-64.

11. Beveridge T, Li TSC, Oomah BD, Smith A. Sea buckthorn products: manufacture and Composition. J Agric Food Chem 1999; 47: 3480-88.

12. Cupara S, Sobajic S, Tadic V, et al. Dry seabuckthorn berries (Hippophae rhamnoides L.) - fatty acid and carotene content in pericarp and seed oil. HealthMed 2010; 4: 788-91.

13. Majewska I, Gendaszewska-Darmach E. Proangiogenic activity of plant extracts in accelerating wound healing - a new face of old phytomedicines. Acta Biochim Pol 2011; 58: 1-12.

14. Suryakumar G, Gupta A. Medicinal and therapeutic potential of Sea buckthorn (Hippophae rhamnoides L.). J Ethnopharmacol 2011; 138: 268-78.

15. Cupara S, Ninkovic M, Knezevic M, Vuckovic I, Jankovic S. Wound healing potential of liquid crystal structure emulsion with sea buckthorn oil. HealthMed 2011; 5: 1218-23.

16. Cupara S, Jankovic S, Arsic I, Tadic V, Jarcevic V. Characterization of seabuckthorn oil emulsion. Mil Med Sci Lett (Voj Zdrav Listy) 2012; 81: 56-60.

17. EPA. Health Effects Test Guidelines, OPPTS 870.2500. Acute Dermal Irritation (EPA 712-C-96-196), Prevention, Pesticides and Toxic Substances. United States Environmental Protection Agency. USA: Washington DC, (1996) 1 - 10. (Accessed in Dec 2012 at http:// www.epa.gov/ocspp/pubs/frs/home/testmeth.htm) 
18. World Health Organization. Part I, Environmental Health Criteria 6, Principles and Methods for Evaluating the Toxicity of Chemicals. Geneva, World Health Organization, 1978. (Accessed in Dec 2012 at http:// www.inchem.org/documents/ehc/ehc/ehc006.htm)

19. Draize JH. Methods for the Study of Irritation and Toxicity of Substances Applied Topically to the Skin and Mucous Membranes. J Pharmacol Experim Therap 1944; 83: 377-90.

20. Draize JH. Dermal Toxicity, Appraisal of the Safety of Chemicals in Foods, Drugs and Cosmetics. AFDO 1975; 46-59.

21. Muller-Goymann C. Liquid crystals in emulsions, creams and gels containing ethoxylated alcohols as surfactants. Pharm Res 1984; 4: 154-8.

22. Suzuki T, Tsutsumi H, Ishida A. Secondary droplet emulsion: mechanism and effects of liquid crystal formation in o/w emulsion. J Dispers Sci Technol 1984; 5: 119-41.
23. Van Ruissen F, Le M, Carroll JM, Van der Valk PGM, Schalkwijk J. Differential effects of detergents on keratinocyte gene expression. J Invest Dermatol 1998; 110: 358-63.

24. Rhein LD, Robbins CR, Fernee K, Cantore R. Surfactant structure effects on swelling of isolated human stratum corneum. J Soc Cosmet Chem 1986; 37: 125-39.

25. Imokawa G. Surfactant-induced depletion of ceramides and other intercellular lipids: implication for the mechanism leading to dehydration of the stratum corneum. Exog Dermatol 2004; 3: 81-98.

26. Badiu D, Roncea F, Rosoiu N. Formulation and pharmaceutical evaluation of three w/o emulsions with mythilus galloprovincialis and rapana venosa lipid extracts. Farmacia 2009; 57: 212-17.

27. Cupara S, Arsic I, Homsek I, Tadic V, Jevtovic I, Petrovic $M$. In vivo case study: Investigation of o/w cream containing sea buckthorn oil on skin moisture. $7^{\text {th }}$ central European Symposium on Pharmaceutical Technology and Biotechnology, 2008, Ljubljana, Farm. Vest. 59: 303-305. 